\title{
GIS-Based Expert Knowledge for Landslide Susceptibility Mapping (LSM): Case of Mostaganem Coast District, West of Algeria
}

\author{
Rachida Senouci $^{1}{ }^{\mathbb{D}}$, Nasr-Eddine Taibi ${ }^{1}$, Ana Cláudia Teodoro ${ }^{2,3, * \mathbb{D}}$, Lia Duarte ${ }^{2,3} \mathbb{D}^{\mathbb{D}}$, Hamidi Mansour $^{4}$ and \\ Rabia Yahia Meddah 5
}

Citation: Senouci, R.; Taibi, N.-E.; Teodoro, A.C.; Duarte, L.; Mansour, H.; Yahia Meddah, R. GIS-Based Expert Knowledge for Landslide Susceptibility Mapping (LSM): Case of Mostaganem Coast District, West of Algeria. Sustainability 2021, 13, 630. https://doi.org/10.3390/su13020630

Received: 3 December 2020

Accepted: 5 January 2021

Published: 11 January 2021

Publisher's Note: MDPI stays neutral with regard to jurisdictional clai$\mathrm{ms}$ in published maps and institutional affiliations.

Copyright: (C) 2021 by the authors. Licensee MDPI, Basel, Switzerland. This article is an open access article distributed under the terms and conditions of the Creative Commons Attribution (CC BY) license (https:// creativecommons.org/licenses/by/ $4.0 /)$.
1 Laboratory of Protection and Development of Coastal Marine Resources and Molecular Systematics, Department of Marine Sciences and Aquaculture, Faculty of Natural and Life Sciences, Abdelhamid Ibn Badis, University of Mostaganem, BP 227, National Road N 11, Kharrouba, Mostaganem 27000, Algeria; rachida.senouci@univ-mosta.dz (R.S.); nasreddine.taibi@univ-mosta.dz (N.-E.T.)

2 Department of Geosciences, Environment and Land Planning, Faculty of Sciences, University of Porto, 4169-007 Porto, Portugal; liaduarte@fc.up.pt

3 Earth Sciences Institute (ICT), Pole of the FCUP, University of Porto, 4169-007 Porto, Portugal

4 Laboratory of Geo Resources, Environments and Natural Risks, Department of Geology, Faculty of Earth Science and the Universe, University of Mohamed Ben Ahmed Oran 2, B.P1 1524 El-M'Naouar, Oran 31000, Algeria; 1_mansou_1@yahoo.fr

5 Laboratory of Geographical Space and Territorial Planning, Department Geography and Land Planning, Faculty of Earth Science and the Universe, University of Mohamed Ben Ahmed Oran 2, B.P1 1524 El-M'Naouar, Oran 31000, Algeria; yahiameddah7rabia@gmail.com

* Correspondence: amteodor@fc.up.pt; Tel.: +351-220402470

\begin{abstract}
Landslides are one of the natural disasters that affect socioeconomic wellbeing. Accordingly, this work aimed to realize a landslide susceptibility map in the coastal district of Mostaganem (Western Algeria). For this purpose, we applied a knowledge-driven approach and the Analytical Hierarchy Process (AHP) in a Geographical Information System (GIS) environment. We combined landslide-controlling parameters, such as lithology, slope, aspect, land use, curvature plan, rainfall, and distance to stream and to fault, using two GIS tools: the Raster calculator and the Weighted Overlay Method (WOM). Locations with elevated landslide susceptibility were close the urban nucleus and to a national road (RN11); in both sites, we registered the presence of strong water streams. The quality of the modeled maps has been verified using the ground truth landslide map and the Area Under Curve (AUC) of the Receiver Operating Characteristic curve (ROC). The study results confirmed the excellent reliability of the produced maps. In this regard, validation based on the ROC indicates an accuracy of 0.686 for the map produced using a knowledge-driven approach. The map produced using the AHP combined with the WOM showed high accuracy $(0.753)$.
\end{abstract}

Keywords: controlling-parameters; remote sensing; GIS; knowledge driven approach; analytical hierarchy process; weighted overlay method

\section{Introduction}

Around the world and in the highlands, landslides are considered one of the most complex geomorphological phenomena. They are recognized as one of the main threats to human lives, both economically and environmentally [1-3]. Earth mass movements, resulting from natural conditions linked to topography, geology and hydrogeology, are defined as landslides [4,5]. Natural events, such as heavy rainfall, which increases the amount of pore water in the rocks; earthquakes; and coastal erosion could contribute to landslide triggering $[5,6]$. The pressure change of the interstitial water may lead to slope instability and therefore to landslides $[7,8]$. Beyond natural conditions, human activities related to construction, mining and deforestation could also contribute to landslides [9-11]. The East of Algeria is more exposed to landslide hazards than the other parts of the 
country. Historically, many important events were recorded, for instance, in the city of Constantine, whose emblematic bridge suffered in 1935 from considerable damage caused by a landslide. The Belouizdad-Kitouni district has also experienced several landslide events. This phenomenon is intensified in Constantine due the chaotic growth of the city. Ain Hammam, a town located in the region of Tizi-Ouzou (central-eastern region of Algerian), is an unstable area of 23 hectares, which presents intense landslide activity due to harsh winters [12,13]. Landslides represent an obstacle for the development of any region since they cause economic losses. Consequently, the prevention of landslide hazards has become an important tool in land use planning and management $[14,15]$. Landslide susceptibility is known as the spatial prediction of landslide occurrence. Therefore, the preparation of Landslide Susceptibility Zonation (LSZ) maps is an important tool. This map indicates the areas prone to landslides and the safe zones [16]. The effective utilization of a landslide map can reduce the potential damage of the event [17]. Landslide susceptibility mapping is based on slope knowledge movement and its controlling factors. The reliability of these maps mainly depends on the quantity and the quality of available data, the scale of work, and the choice of the appropriate methodology [14,17-20].

Evaluation and mapping of landslide susceptibility has been developed during the last decades using different methods [21,22]. Accordingly, the involved processes could be categorized into qualitative and quantitative approaches. These techniques have been attempted in order to produce more accurate results $[18,23,24]$. The qualitative methods (heuristic) are relatively descriptive and subjective; they are based on expert knowledge of landslide susceptibility and hazard mapping $[25,26]$. The qualitative approach is classified into two groups: (1) the first category is geomorphologic analysis, which is a direct method based on the recognition and experience of scientists in direct landslide susceptibility mapping $[27,28] ;(2)$ the second category represents indirect methods, which are semiquantitative where all the parameters that influence the landslide occurrence are ranked and a weight value is assigned based on expert knowledge. Furthermore, the ratings and weights of the controlling parameters can be estimated using the expert's opinion (knowledge-driven approach) and the analytical hierarchy process (AHP). The AHP is a multi-criteria decision approach that involves a matrix based on the pairwise comparison of landslide-controlling parameters. The Weighted Linear Combination (WLC) method has been used to combine different factors in which each parameter is multiplied by its assigned weight. The results of qualitative approaches mainly depend on expert knowledge. The qualitative method does not require any inventory map for landslide susceptibility mapping $[17,20,29,30]$.

In the quantitative approach, two methods are distinguished: deterministic and statistical. The deterministic method is based on the calculation of safety factors for slope stability studies [31]. It is applied on individual sites due to the difficulty of acquiring the spatial variability of geotechnical and phreatic parameters [32]. Statistical methods, such as bivariate and multivariate statistical methods, Frequency Ratio (FR), Weight of Evidence (WoE), Artificial Neural Network (ANN), and Support Vector Machine (SVM), are based on analysis of the relations between conditioning factors and landslide events distribution [20,33-38]. The selection of an adequate method depends on the scale of the study area, the availability of data, and scientific knowledge [39].

In Algeria, the evaluation of landslide susceptibility is a new field. Some authors have used heuristic and statistical techniques to identify the different sites prone to landslides. The majority of the study cases were located in the East of the country [40-43]. A landslide susceptibility study was carried out in the Arzew sector (North-Western Algeria) [44]. These researchers mostly used statistical techniques [40-44]. Bourenane et al. [40] followed a geomorphological analysis method for landslide susceptibility mapping. The different works are described in Table 1. 
Table 1. Different works on landslide susceptibility in Algeria.

\begin{tabular}{|c|c|c|c|c|}
\hline & Authors & Study Area & Parameters & Techniques \\
\hline \multirow{4}{*}{ East of Algeria } & Bourenane et al., 2014 [40] & City of Constantine & $\begin{array}{l}\text { Slope gradient, slope aspect, } \\
\text { lithology, precipitation, distance } \\
\text { to stream, land use, distance to } \\
\text { road, distance to faults }\end{array}$ & $\begin{array}{l}\text { Geomorphological } \\
\text { analysis \& SI }\end{array}$ \\
\hline & Achour et al., 2017 [42] & $\begin{array}{l}\text { Highway } \\
\text { section/Constantine } \\
\text { province }\end{array}$ & $\begin{array}{l}\text { Lithology, distance to faults, } \\
\text { slope gradient, slope aspect, } \\
\text { distance from streams, land use, } \\
\text { cohesion, internal friction }\end{array}$ & AHP \& IV \\
\hline & Manchar et al., 2018 [43] & Constantine city & $\begin{array}{l}\text { Lithology, slope gradient, slope } \\
\text { aspect, elevation, distance to } \\
\text { lineaments, distance to stream, } \\
\text { rainfall, NDVI }\end{array}$ & IV, WoE \& FR \\
\hline & Hadji et al., 2018 [16] & Oued Mellah Basin & $\begin{array}{l}\text { Lithology, faults, slope, } \\
\text { elevation, aspect, streams, roads } \\
\text { and precipitation }\end{array}$ & AHP, LI \& LR \\
\hline \multirow{2}{*}{ West of Algeria } & $\begin{array}{l}\text { Roukh and Abdelmansour } \\
\qquad(2018)[44]\end{array}$ & Arzew Sector & $\begin{array}{l}\text { Slope angle, slope exposure, } \\
\text { lithology, distance to streams, } \\
\text { land use, distance to road, } \\
\text { altitude, }\end{array}$ & IV \& FR \\
\hline & Current study & Mostaganem coast district & $\begin{array}{l}\text { Lithology, slope, land use, slope } \\
\text { aspect, plan curvature, rainfall, } \\
\text { distance to streams, distance to } \\
\text { roads and distance to fault }\end{array}$ & $\begin{array}{l}\text { Knowledge driven } \\
\text { approach and AHP } \\
\text { combined to WOM }\end{array}$ \\
\hline
\end{tabular}

SI: Statistical Index; FR: Frequency Ratio; IV: Information Value; WoE: Weight of Evidence; LI: Linear Indexing; LR: Logistic Regression; NDVI: Normalized Difference Vegetation Index.

Our work assesses landslide susceptibility in the coastal district of Mostaganem (West Algeria). This area is mainly composed of alluvium, consolidated dunes, and beaches features. Although this lithology is brittle, built-up construction projects have been planned without an impact study being required by law. As a result, several landslide cases have been recorded in this area in the last years [45].

In this work, a semi-quantitative approach, based on expert knowledge of landslide susceptibility mapping, was followed. This approach constitutes a bridge between qualitative and quantitative methods by evaluating the importance of different parameters in the generation of landslide susceptibility maps using a knowledge-driven approach and AHP, combined with WOM methods within a GIS environment. The results could be an opportune guideline for land planning in the Mostaganem area $[27,46]$.

\section{Materials and Methods}

\subsection{Study Area}

Mostaganem is a coastal province located in the North-West of Algeria. Its $124 \mathrm{~km}$ coastline is made up of ten districts and a river (Oued Cheliff), which divides the province into two parts. The Eastern part is poorly urbanized and has huge beaches, dunes, littoral plains, and forests. The Western part is highly urbanized [47]. As one of the main coastal cities in Algeria, Mostaganem has been intensively urbanized (littoralization) and its sand dunes overexploited for construction needs [48,49]. The necessary preservation of the natural resources led to the introduction of the Littoral Law in February 2002, which stipulates the protection and the valorization of the coastal zone. According to the Littoral Law, built-up activities are consequently prohibited within the $300 \mathrm{~m}$ coastal strip. Nevertheless, construction projects have already been initiated with the aim of increasing residential buildings and boosting tourism.

From a morphological point of view, the coastal zone of the Mostaganem province extends over $2120 \mathrm{~km}^{2}$, where $53 \%$ are covered by forest. The study area (Figure 1) represents $52 \mathrm{~km}^{2}$ and $37.82 \mathrm{~km}$ of coastline, covering two districts: Mostaganem (urban nucleus) and Ben Abdelmalek Ramdane. The Western part of the study area is composed of consolidated dunes (cliffs) situated around Mostaganem city. The Eastern part is located 
in the zone of Ben Abdelmalek Ramdane, where plains are mainly composed of sand, marl and, in a few locations, alluvium. The valley corresponding to Oued Cheliff separates the study area in two geomorphological units: the shoreline parallel to the Eastern plain and the shelf of Mostaganem; the latter includes mobile dunes, consolidate dunes and beaches [50-53]. Meteorological conditions in the coastal Mostaganem district correspond to a semi-arid Mediterranean climate, characterized by dry, hot summers and rainy winters.
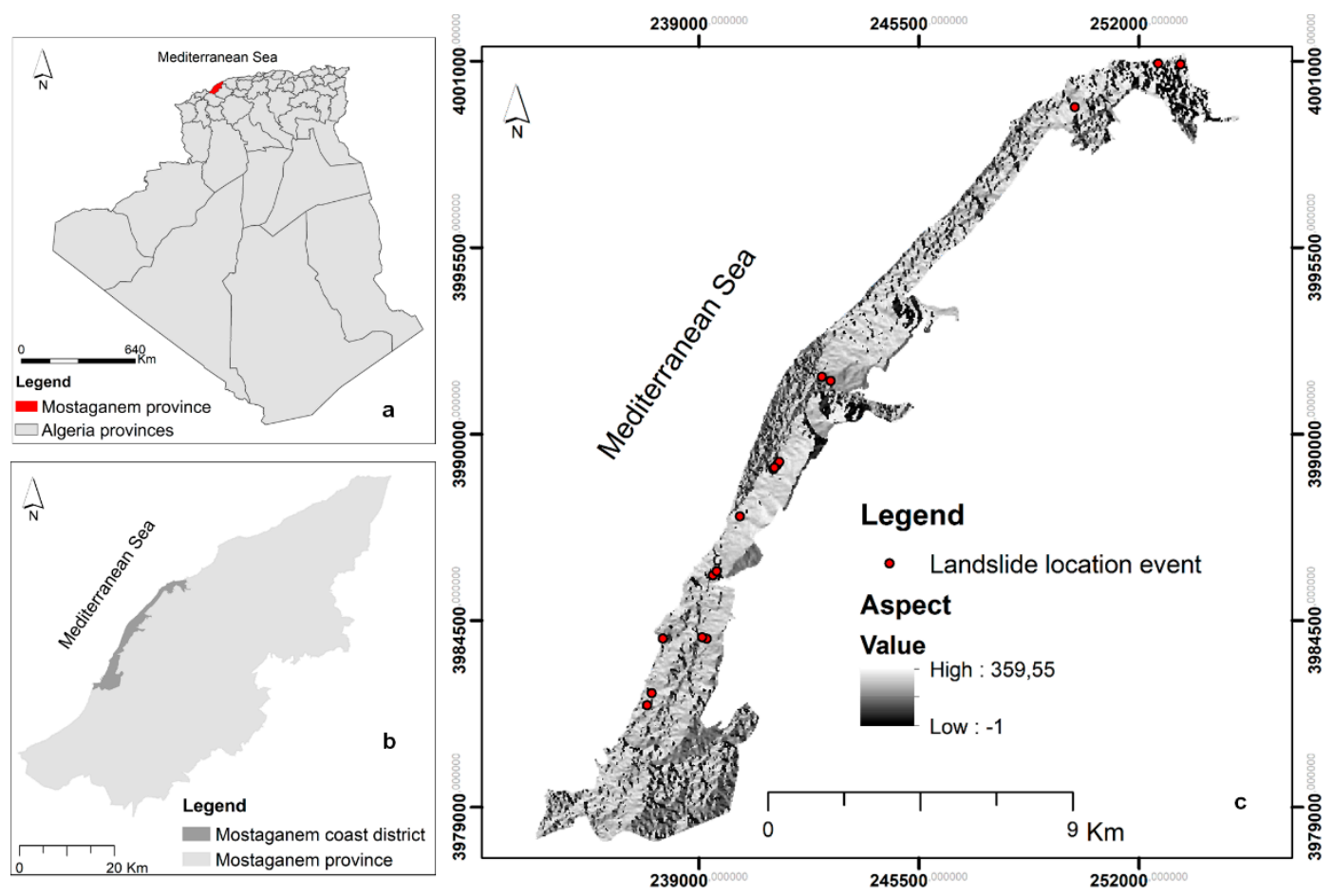

Figure 1. Geographical location of the study area: (a) geographical position of Mostaganem province in Algeria; (b) position of the coast district in the Mostaganem province; (c) Mostaganem coast district location.

Figure 2 describes the methodology followed in this paper. This work was initiated by collecting data from different sources (reports, newspaper, interviews) and Global Navigation Satellite System (GNSS) data to construct a landslide inventory. Then, the different parameters controlling landslides were extracted, considering a GIS environment (ArcGIS 10.5.1). A knowledge-driven approach and (AHP), combined with WOM, was applied to map landslide susceptibility. In order to compare the two produced maps, a Fuzzy Linear membership function (FL) was applied. In the end, the quality of the produced maps was verified.

\subsection{Landslide Inventory Map}

The landslide inventory map is a key step for landslide susceptibility prediction $[54,55]$. This map can be used to prevent events that could occur in unstable areas and compare them with the modelled landslide susceptibility map [2,21,56-58]. The landslide inventory map could be produced on local, regional or national scales; its conception basically depends on the scope of the study $[19,46,59,60]$. In our study area, we identified 17 cases of landslide events during the period between 2016 and 2019 (Figure 1). The compilation of the landslide inventory map was accomplished through a range of interviews with administrative personals such as the National Coastal Commission (Commissariat National $\mathrm{du}$ Littoral) and the Directorate of Public Works of Mostaganem province. Interviews with the local residents of Mostaganem were also performed. The use of Google Earth, local newspapers, and some reports published by the Laboratory of Maritime Studies (LEM/Algiers) was also necessary to complete our database. Furthermore, intensive field 
surveys were performed for three years (2017-2019) in order to validate the collected data and identify the locations. Based on interviews, reports analysis and field surveys, different geological hazard events that occurred recently were identified (Figure 3). The recorded cases are mainly shallow; they occurred in soils at depths ranging from a few decimeters to a few meters. These events took place close to the urban area, near the network of roads that has been constructed on the consolidated dune system, a feature with high susceptibility to coastal hazards.

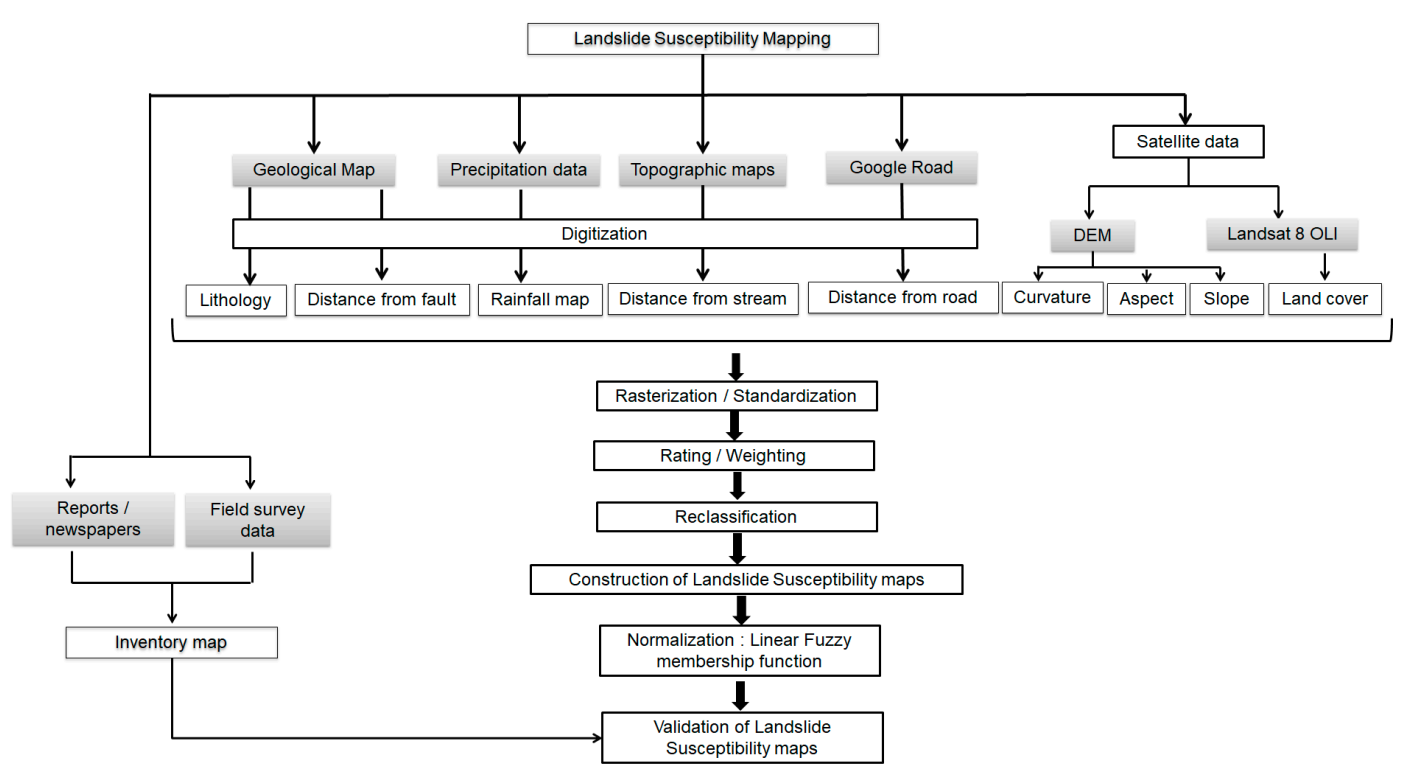

Figure 2. Flowchart showing the different steps followed in this study.

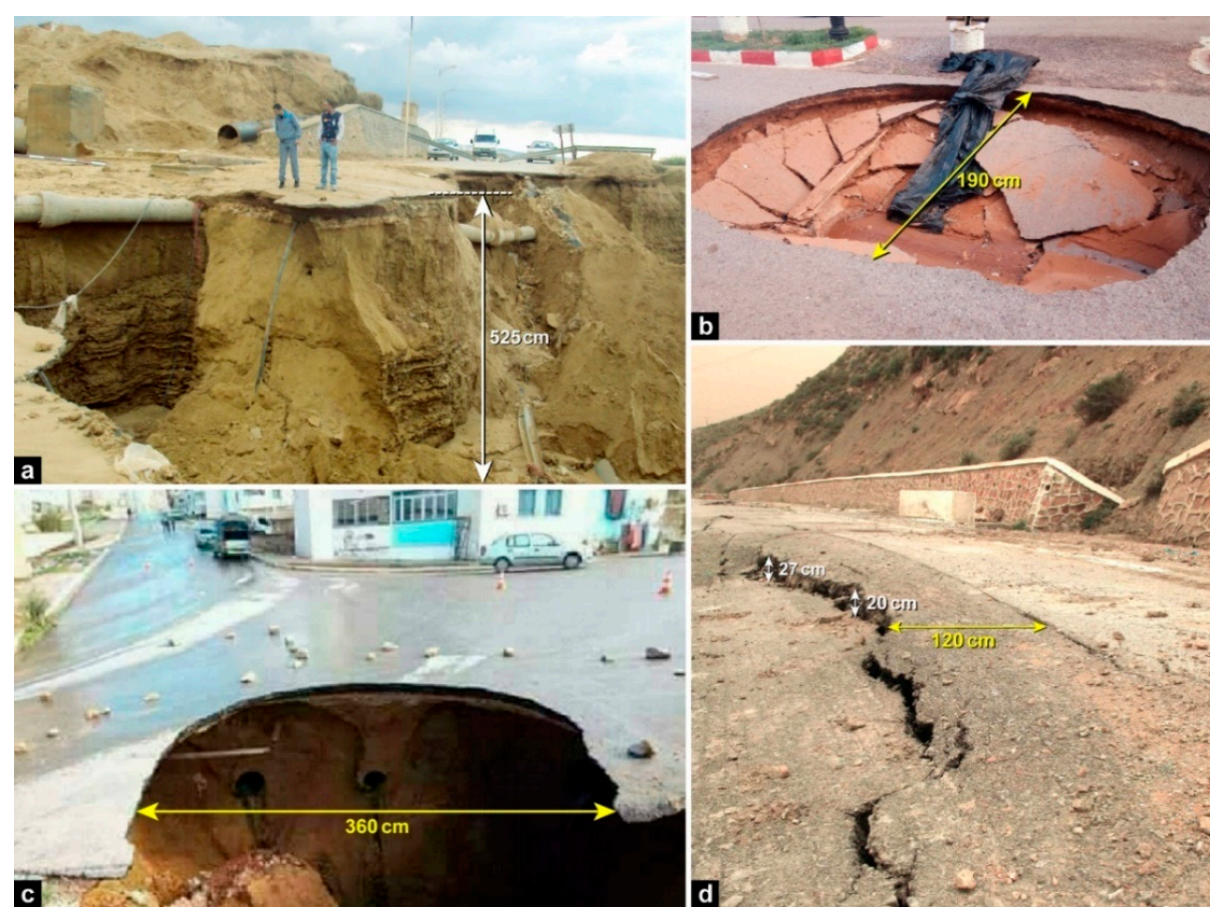

Figure 3. Photographs showing landslide events in the Mostaganem coast district: (a) Cliff of Sid El Mejdoub, (b) Parking (Mostaganem University/site V), (c) Hai Salam, and (d) National Road N 11 (combined by ADOBE ILLUSTRATOR). 


\subsection{Description of Parameters}

\subsubsection{Lithology}

Lithology is an important parameter in landside occurrence and susceptibility mapping $[37,43,61,62]$. The digitizing of the geological map of Bosquet-Mostaganem (scale: $1 / 200,000$ ) allowed for the identification of 10 lithological units in the study area (Figure 4a). The main registered rocks belong to Quaternary, Pliocene, and Miocene.

\subsubsection{Slope}

In landslide susceptibility studies, slope is considered one of the most important parameters of slope failure. It was derived from SRTM DEM (Shuttle Radar Topography Mission Digital Elevation Model) with $30 \mathrm{~m}$ of spatial resolution, and it was classified into 5 classes (Figure $4 \mathrm{~b}$ ). As is known, the probability of landslide occurrence increases where the slope is steeper compared with gentler ones [63].
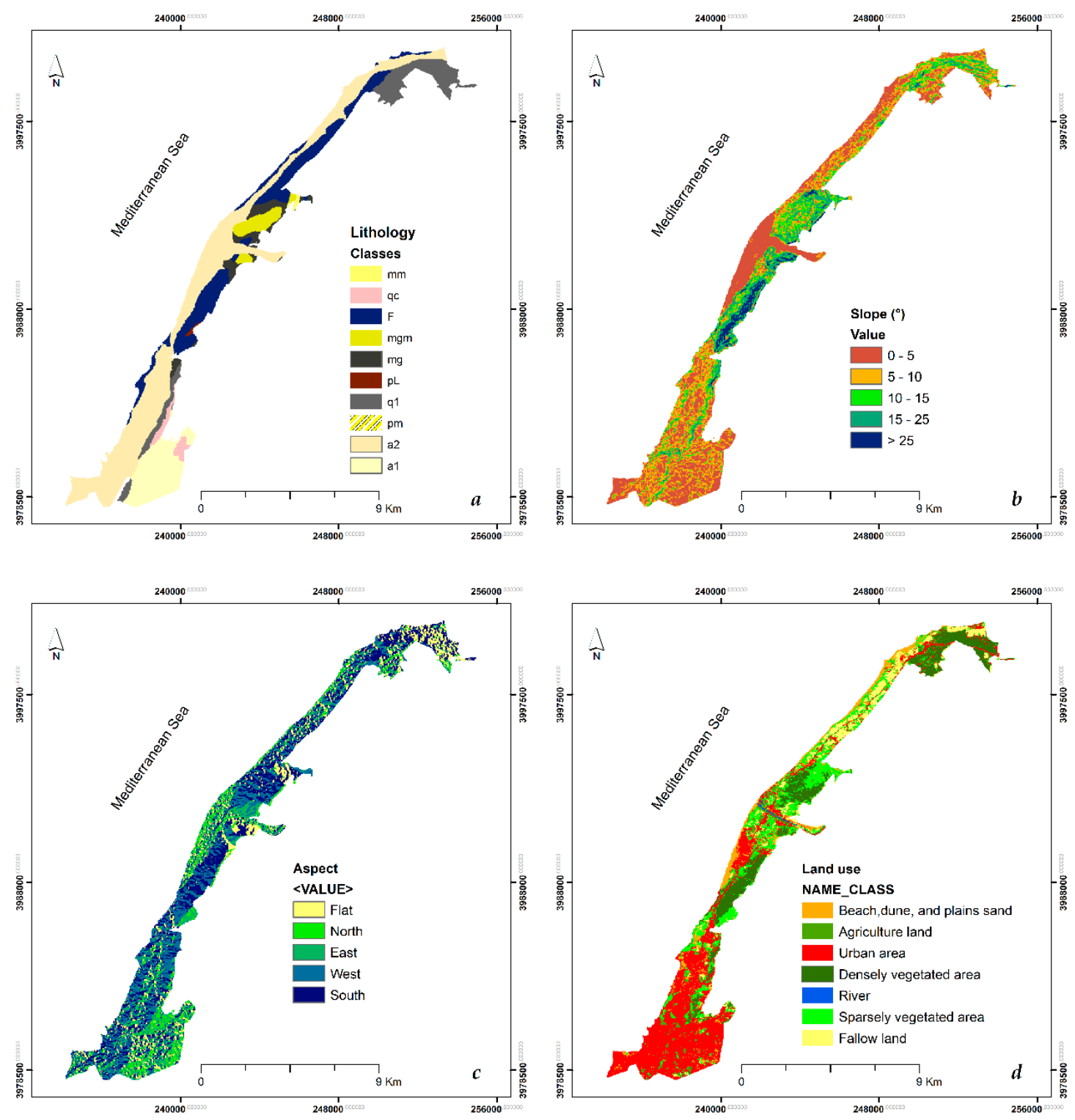

Figure 4. Cont. 

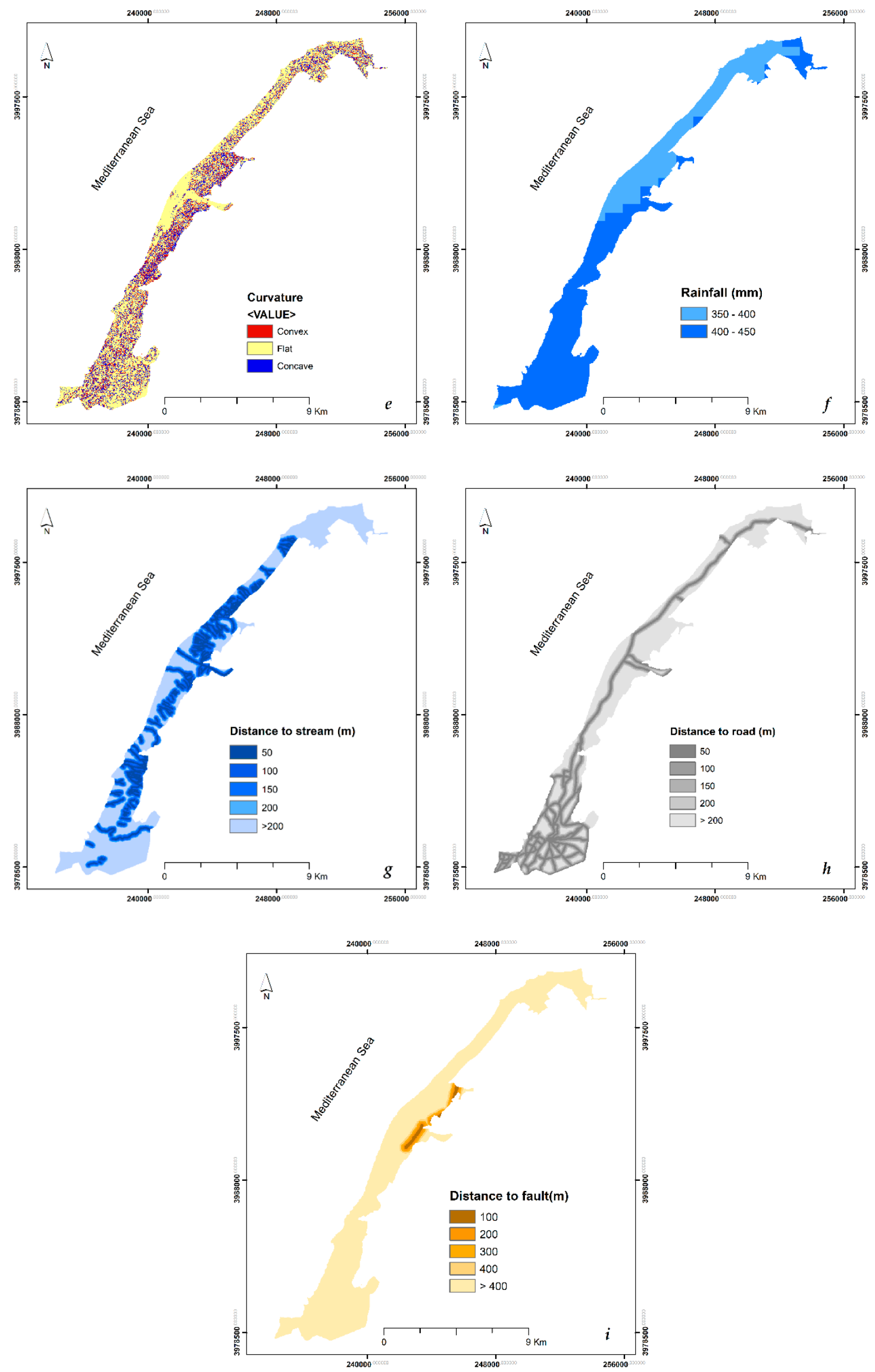

Figure 4. (a) Lithology; (b) slope; (c) land use; (d) aspect; (e) curvature plan; (f) rainfall; (g) distance to stream; (h) distance to road; and (i) distance to fault (Datum reference: WGS 84, UTM Zone 31). 


\subsubsection{Land Use}

Land use is one of the key factors influencing the stability of slopes $[64,65]$. The non-organized distribution of constructions on brittle and steep terrains could increase landslide occurrence [66,67]. Vegetation coverage also plays a vital role in landslide events reduction due to its root structure, which adds strength to the soil and provides ground solidity, thus mitigating the erosive effect of hydrological agents $[36,68]$. In this work, the evaluation of the impact of land cover types on landslide occurrence was performed by processing a satellite image from Landsat-8 Operational Land Imager (OLI) (acquired in October 2017). Furthermore, the Maximum Likelihood (ML) algorithm was applied to the satellite image using ENVI 4.8 software in order to perform a supervised classification [69]. The studied site was divided into 7 classes: urban area, sparsely vegetated area, river, fallow land, densely vegetated area, beach-dune and sand plains, and agriculture land (Figure 4c). The produced map showed an overall accuracy of $94.79 \%$, considering the analysis of the confusion matrix (Figure 4c).

\subsubsection{Slope Aspect}

The slope aspect is a crucial geomorphological component in landslide investigations, since it has indirect action on slope instability. The slope aspect is mainly related to climatic agents such precipitation, runoff surface, sun exposure, and dry wind, which subsequently influence soil moisture, vegetation and, ultimately, landslide occurrence [68,70-72]. In this work, the slope aspect was derived from SRTM DEM with $30 \mathrm{~m}$ of spatial resolution and divided into 5 classes: Flat, North, East, South and West (Figure 4d).

\subsubsection{Plane Curvature}

The curvature plane, which is defined as the change rate of slope angle or aspect [73,74], can take 3 slope shapes: flat, convex, and concave. High values of the plane curvature correspond to a convex shape of the slope; conversely, low values mean the slope is concave. This factor has a significant influence on the runoff surface. In general, convex areas disperse runoff equally and consequently do not affect slope stability. However, concave surfaces contribute to the accumulation of water in the lowest part, leading to the occurrence of landslides. In this study, the plane curvature was derived from SRTM DEM in a GIS environment (Figure 4e).

\subsubsection{Rainfall}

Rain is considered one of the most important factors in the occurrence of landslides [75,76]. Rainwater infiltration increases soil moisture and, subsequently, a decrease in shear strength and soil cohesion, which induces its instability $[46,77,78]$. In the province of Mostaganem, considerable rainfalls occur mainly in December and January [51], since the East of Algeria is rainier than the West. In the current study, we obtained this parameter by digitizing the rainfall map of Algeria $(1 / 200,000)$ and dividing our area into 2 classes $(350-400 \mathrm{~mm}$ and $400-450 \mathrm{~mm}$; Figure $4 \mathrm{f}$ ). For the two approaches we followed, the rank and weight of this parameter were assigned based on expert knowledge.

\subsubsection{Distance to Stream}

The province of Mostaganem has a significant land aquifer $[79,80]$. This resource could indicate the high density of streams in the region. The distance to stream plays a crucial role in landslide phenomena. It could affect slope stability where the streams saturate the lower part of the soil, increasing its water level $[17,81]$. Methodologically, the streams were digitized from a topographic map $(1 / 25,000)$. Furthermore, a multi-stream buffer was created using GIS software tools and divided into 5 classes with a $50 \mathrm{~m}$ interval (Figure $4 \mathrm{~g}$ ).

\subsubsection{Distance to Roads}

The road network is an important anthropogenic feature that could also affect the stability of the terrain [82]. The RN11 (Route Nationale) is the most important road located 
in the study area. Methodologically, we digitized the road network, extracted from Google Road using the Quick Map Services Plugin available in open-source GIS software (QGISversion 3.8). Furthermore, a multi buffer was created in a GIS environment, in which five classes with $50 \mathrm{~m}$ intervals were grouped (Figure $4 \mathrm{~h}$ ).

\subsubsection{Distance to Fault}

The areas close to active faults are weak, and consequently, their susceptibility to instability increases. In the coastal district of Mostaganem, faults were obtained through the digitization of the geological map of Bosquet-Mostaganem (1/200,000). A multi buffer was computed with an interval of $100 \mathrm{~m}$, using GIS tools. The distances to the fault were grouped into 5 classes (Figure 4i).

\subsection{Landslide Susceptibility Analysis}

\subsubsection{Knowledge-Driven Approach}

The knowledge-driven approach is a qualitative method; it can be either direct or indirect. The direct method is based on direct geomorphological mapping of the geological hazard. However, the indirect method is based on assigning ratings and weights depending on the influence of controlling factors for landslide triggering $[83,84]$. The success of this approach is mainly based on expert knowledge [27]. In this work, a value between 1 to 5 was assigned to the factors. The highest value was assigned to factors and their subclasses with an important influence on landslide occurrence, and vice vera $[85,86]$. The landslide susceptibility map was produced using the Raster Calculator tool from GIS software according to Equation (1).

$$
\begin{gathered}
L S M\left(K_{-} D\right)=(W \alpha \times \alpha)+(W \beta \times \beta)+(W \gamma \times \gamma)+(W \delta \times \delta)+(W \varepsilon \times \varepsilon)+(W \lambda \times \lambda)+(W \mu \times \mu) \\
+(W \tau \times \tau)+(W \omega \times \omega)
\end{gathered}
$$

where LSM $\left(K \_D\right)$ is the Landslide Susceptibility Map produced according to the knowledgedriven approach; $\alpha$ is the lithology; $\beta$ is the Slope; $\gamma$ is the land use; $\delta$ is the slope aspect; $\varepsilon$ is the curvature plan; $\lambda$ is the rainfall; $\mu$ is the distance to stream; $\tau$ is the distance to road; $\omega$ is the distance to fault; $W \alpha$ is the weight of lithology factor; $W \beta$ is the weight of slope; $W \gamma$ is the weight of land use; $W \delta$ is the weight of slope aspect; $W \varepsilon$ is the weight of curvature; $W \lambda$ is the weight of rainfall; $W \mu$ is the weight of distance to stream; $W \tau$ is the weight of distance to road; and $W \omega$ is the weight of distance to fault.

\subsubsection{Analytical Hierarchy Process (AHP)}

The AHP, introduced by Saaty (1980), is a multi-criteria decision-making (MCDM) method, used in various research fields due to its simplicity and flexibility. Therefore, the mapping of landslide susceptibility is one of the domains that most uses the AHP [17]. This process, which consists of assigning weights to landslide-controlling factors [8,87], makes its application possible. Generally, the AHP method comprises 3 steps: (1) decomposition of the problem into different hierarchical levels, in which high levels represent the main objectives of decision-making; (2) comparative judgment through the pairwise comparison of factors; and (3) synthesis of the proprieties according to the importance of each factor, based on the literature and expert knowledge. Furthermore, in order to describe the relationship existing between different factors, a numerical value based on the AHP was assigned to each factor (Table 2). The pairwise comparison matrix was created through dual comparison between different factors. Weights were determined based on the normalization of the eigenvector, which corresponds to the largest eigenvalue of the ratio matrix. With reference to the comparison, different judgments could be reached by experts. 
Table 2. Scale of preference between two parameters in the Analytical Hierarchy Process (AHP) [29].

\begin{tabular}{|c|c|c|}
\hline Intensity of Factors & Degree of Intensity & Explanation \\
\hline 1 & Equal importance & The two parameters contribute to the same objective \\
\hline 3 & Moderate Importance & $\begin{array}{l}\text { The experience or judgment slightly favours one } \\
\text { parameter over another }\end{array}$ \\
\hline 5 & Strong importance & A parameter is favoured strongly over another \\
\hline 7 & Very strong importance & $\begin{array}{l}\text { A parameter is favoured very strongly over another, and } \\
\text { it shows in practice }\end{array}$ \\
\hline 9 & Extreme importance & $\begin{array}{l}\text { The evidence of favouring one parameter over another is } \\
\text { of the highest degree possible to affirm }\end{array}$ \\
\hline $2,4,6,8$ & Intermediate value between two adjacent judgments & $\begin{array}{l}\text { Used to represent the comprises between the preference } \\
\text { scores } 1,3,5,7 \text { and } 9\end{array}$ \\
\hline Reciprocals & Opposites & Used for inverse comparisons \\
\hline
\end{tabular}

The Consistency Ratio (CR) was computed to describe the quality of judgments according to Equation (2).

$$
C R=\frac{C I}{R I}
$$

$R I$ is the Random Index depending on the order of matrix given in Table 3 [29]. CI is the Consistency index, computed using Equation (3):

$$
C I=\frac{(\lambda \max -n)}{(n-1)}
$$

where $\lambda$ max is the maximum eigenvalue of matrix, and $n$ is the order of matrix.

Table 3. Random consistency index (RI).

\begin{tabular}{cccccccccc}
\hline $\boldsymbol{n}$ & $\mathbf{2}$ & $\mathbf{3}$ & $\mathbf{4}$ & $\mathbf{5}$ & $\mathbf{6}$ & $\mathbf{7}$ & $\mathbf{8}$ & $\mathbf{9}$ & $\mathbf{1 0}$ \\
\hline $\mathrm{RI}$ & 0 & 0.58 & 0.9 & 1.12 & 1.24 & 1.32 & 1.41 & 1.45 & 1.51 \\
\hline
\end{tabular}

If the $\mathrm{CR}$ value is lower than $10 \%$, it means the assigned weights of the factors are consistent [81]. If the CR is higher than $10 \%$, it indicates that the comparisons are not consistent, which consequently requires a revision. In our work, the AHP was applied in order to determine the ranking and weights of each class. Regarding the precipitation parameter, the ranking of classes was given directly based on expert knowledge.

\subsubsection{Weighted Overlay Method (WOM)}

The WOM is a simple, direct and adequate tool available in GIS environments that is used widely to solve multi-criteria problems, such as landslide susceptibility $[87,88]$. This method consists of a combination of different factors considering its given weights [84,89]. In this study, ranking values and parameter weights have been determined using AHP. In order to produce the predicting landslide susceptibility map, all the parameters were integrated in a WOM tool within a GIS environment. The summation of weights must be equal to 100. Accordingly, each weight was multiplied by its assigned factor according to Equation (4).

$$
L S M=\Sigma\left(X_{i} \times W_{i}\right)
$$

where $X_{i}$ is the ranking of each class, and $W_{i}$ is the weight of the controlling-parameter.

\subsubsection{Normalization}

Zadeh (1965) [90] introduced fuzzy set logic for the first time, and it has been widely applied in different research areas and on distinct measurement due to its straight forwardness [91,92]. In this logic, all objects are considered as elements of a set. In fuzzy theory, 
each element can take a value ranging from 0 to 1 [74,93]. According to this method, many researchers have combined it with AHP in order to improve the accuracy of the assessment of landslide susceptibility mapping [17,94-96].

In this work, we produced two different maps in terms of scale value (the value classes), applying two methods: the knowledge-driven approach and the AHP combined with WOM. Considering this, it was possible to compare both maps and eliminate uncertain values. Furthermore, the fuzzy linear membership function was applied with the aim to convert the input data linearly on the 0 to 1 scale, in which the value 0 is assigned to the lowest input data and value 1 to the highest input value; normalization was processed in GIS software.

\section{Results}

\subsection{Knowledge-Driven Approach}

Based on the knowledge-driven approach, the evaluation integrated several parameters such as lithology, slope, land cover, aspect, curvature, rainfall, distance to stream, distance to road and distance to fault. All the factors were ranked and weighted based on their importance. A numerical scale (1-5) from low to high influencing was applied. The most influential factors were: lithology, slope, land cover, and aspect. Curvature plane, rainfall, distance to stream, and distance to road are equally important with respect to slope instability. Distance from faults increases the likelihood of landslide occurrence [37]. However, in this study case, this factor does not contribute much to landslide triggering. To produce the landslide susceptibility map (Figure 5a), the sum of each parameter multiplied by its correspondent weight was performed in the Raster Calculator tool, considering Equation (1).
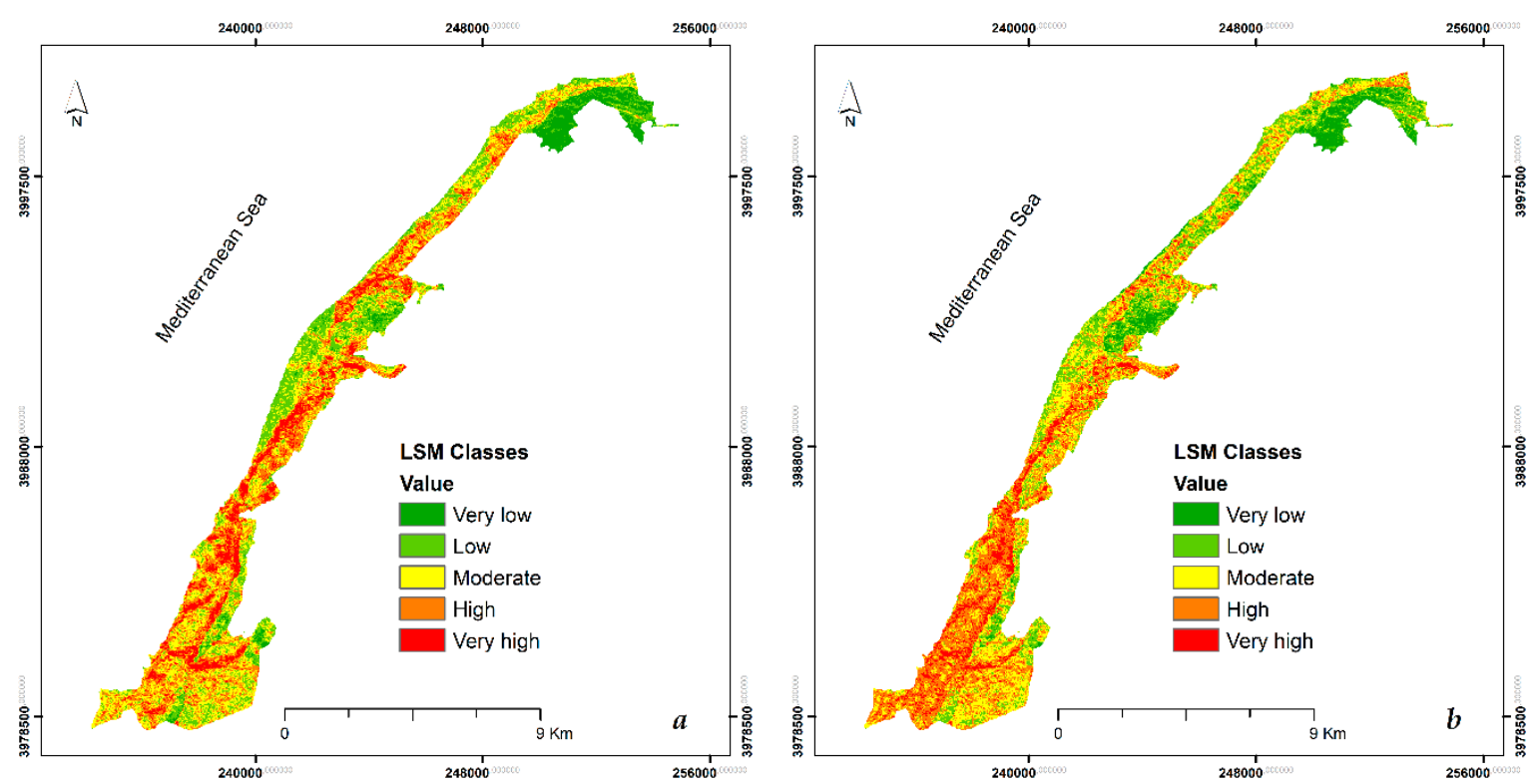

Figure 5. Landslide susceptibility map of (a) the knowledge-driven approach and (b) the AHP method combined with WOM.

\subsection{Analytical Hierarchy Process Weights}

The AHP was applied to estimate the weights and ratings for class factors: lithology, slope, aspect, land; both can be obtained from the pair wise comparison matrix. The matrix was applied on two levels: (i) to assess the class rating of each parameter and (ii) to estimate the weights parameter through Python scripts in GIS software. As illustrated in Table 4, lithology was the most influential parameter, with a value of 0.280 . The classes quaternary continental alluvium and sand presented ranking values of 0.29 and 0.26 , respectively; 
these classes make the lithological factor more influential for landslide triggering. They presented values of 0.29 and 0.26 , respectively. The slope also had a considerable value of 0.164 , followed by land use, with 0.154 , and curvature plane, with 0.111 . The factors distance to stream, distance to road, and rainfall were less important. However, the distance to fault was of minor influence.

Table 4. Estimation of ratings and weights based on the knowledge-driven approach and AHP process.

\begin{tabular}{|c|c|c|c|c|c|}
\hline \multirow[b]{2}{*}{ Parameter } & \multirow[b]{2}{*}{ Classes } & \multicolumn{2}{|c|}{ Knowledge Driven Approach } & \multicolumn{2}{|c|}{ AHP Method } \\
\hline & & Rating & Weight & Rating & Weight \\
\hline \multicolumn{6}{|l|}{ Lithology } \\
\hline & $a^{1}$ & 5 & 5 & 0.260 & 0.280 \\
\hline & $a^{2}$ & 5 & & 0.290 & \\
\hline & $\mathrm{F}$ & 4 & & 0.120 & \\
\hline & $\mathrm{m}^{\mathrm{m}}$ & 3 & & 0.090 & \\
\hline & $\mathrm{p}^{\mathrm{m}}$ & 3 & & 0.100 & \\
\hline & $\mathrm{mg}$ & 2 & & 0.030 & \\
\hline & $\mathrm{mgm}$ & 2 & & 0.030 & \\
\hline & $q^{c}$ & 2 & & 0.030 & \\
\hline & $\mathrm{p}^{\mathrm{L}}$ & 1 & & 0.024 & \\
\hline & $\mathrm{q}^{1}$ & 2 & & 0.026 & \\
\hline \multicolumn{6}{|l|}{ Slope $\left(^{\circ}\right)$} \\
\hline & $0-5$ & 1 & 4 & 0.073 & 0.164 \\
\hline & 05-10 & 2 & & 0.110 & \\
\hline & $10-15$ & 3 & & 0.161 & \\
\hline & $15-25$ & 4 & & 0.259 & \\
\hline & $>25$ & 5 & & 0.395 & \\
\hline \multicolumn{6}{|l|}{ Land cover } \\
\hline & Sparsely vegetated area & 5 & 3 & 0.368 & 0.154 \\
\hline & Built-up area & 4 & & 0.319 & \\
\hline & Beach, Dune and sand plains & 3 & & 0.097 & \\
\hline & Fallow land & 3 & & 0.098 & \\
\hline & Agriculture land & 2 & & 0.046 & \\
\hline & Forest & 2 & & 0.045 & \\
\hline & River & 1 & & 0.033 & \\
\hline \multicolumn{6}{|l|}{ Aspect } \\
\hline & Flat & 1 & 3 & 0.062 & 0.111 \\
\hline & North & 2 & & 0.114 & \\
\hline & East & 3 & & 0.171 & \\
\hline & South & 4 & & 0.146 & \\
\hline & West & 5 & & 0.504 & \\
\hline \multicolumn{6}{|c|}{ Curvature plane } \\
\hline & Concave & 5 & 2 & 0.619 & 0.086 \\
\hline & Flat & 1 & & 0.096 & \\
\hline & Convex & 3 & & 0.284 & \\
\hline \multicolumn{6}{|c|}{ Rainfall (mm) } \\
\hline & $350-400$ & 2 & 2 & 0.250 & 0.057 \\
\hline & $400-450$ & 3 & & 0.750 & \\
\hline
\end{tabular}


Table 4. Cont.

\begin{tabular}{|c|c|c|c|c|c|}
\hline \multirow[b]{2}{*}{ Parameter } & \multirow[b]{2}{*}{ Classes } & \multicolumn{2}{|c|}{ Knowledge Driven Approach } & \multicolumn{2}{|c|}{ AHP Method } \\
\hline & & Rating & Weight & Rating & Weight \\
\hline \multicolumn{6}{|c|}{ Distance to stream (m) } \\
\hline & 50 & 5 & 2 & 0.552 & 0.077 \\
\hline & 100 & 4 & & 0.189 & \\
\hline & 150 & 3 & & 0.137 & \\
\hline & 200 & 2 & & 0.077 & \\
\hline & $>200$ & 1 & & 0.041 & \\
\hline \multicolumn{6}{|c|}{ Distance to road (m) } \\
\hline & 50 & 5 & 2 & 0.537 & 0.043 \\
\hline & 100 & 4 & & 0.202 & \\
\hline & 150 & 3 & & 0.129 & \\
\hline & 200 & 2 & & 0.081 & \\
\hline & $>200$ & 1 & & 0.052 & \\
\hline \multicolumn{6}{|c|}{ Distance to fault (m) } \\
\hline & 100 & 5 & 1 & 0.480 & 0.028 \\
\hline & 200 & 4 & & 0.229 & \\
\hline & 300 & 3 & & 0.161 & \\
\hline & 400 & 2 & & 0.089 & \\
\hline & $>400$ & 1 & & 0.041 & \\
\hline
\end{tabular}

Note: $\mathrm{a}^{1}$ : quaternary continental sand; $\mathrm{a}^{2}$ : quaternary continental alluvium; F: flysch slick (thitonian upper cretaceous); $\mathrm{m}^{\mathrm{m}}$ : blue marl (à cénirite); $\mathrm{p}^{\mathrm{m}}$ : plaisancian marl blue; $\mathrm{m}^{\mathrm{g}}$ : sandstone, conglomerate with red clay; $\mathrm{m}^{\mathrm{gm}}$ : sandstone and sand (sedra-tliouanet level); $\mathrm{q}^{\mathrm{c}}$ : post-villafranchian: calcareous carapace; $\mathrm{p}^{\mathrm{L}}$ : plaisancian calcareous lithothamnium; $\mathrm{q}^{1}$ : calcareous lumachel standstone (calabrian).

The values of the CR were less than $10 \%$ (Table 4), which is in accordance with the consistency of the pair-wise comparison. Consequently, these results confirm the validity of the factors' ratings and weights [17]. Accordingly, several parameters were integrated into the GIS environment using a WOM tool, and each parameter was multiplied by its assigned weight to generate the landslide susceptibility map (Figure 5b) according to Equation (4).

\subsection{Landslide Susceptibility Analysis}

LSM showed different ranges of CVs (value classes); LSM based on the knowledgedriven approach showed a CV comprised between $(30,112)$ (Figure 5a), while LSM produced using the AHP weight combined with the WOM had a CV ranging from $(6,39)$ (Figure $5 b$ ).

In order to compare the results, the $\mathrm{CV}$ of the output layers was normalized on the numerical scale $(0,1)$, using a fuzzy linear membership function and the Natural Breaks classification (Jenks), which is simple and based on natural groupings inherent in the data. Class Breaks enable the grouping of similar values and maximize the differences between classes [70,78].

The LSM maps were grouped into 5 classes: very low, low, moderate, high and very high (Figure 5). The very low areas susceptible to landslides cover $3.823 \mathrm{~km}^{2}$ (Figure 5a); they are mainly located in densely vegetated areas. Plant roots provide high stability to the soil, and consequently no landslide event has been recorded in this class (Figure 6a). The zone with low susceptibility to landslides covers $11.484 \mathrm{~km}^{2}$. These areas belong to the beach, dune, and sand class corresponding to a very low slope $\left(0-5^{\circ}\right)$. The moderate class covers an extended area of $16.329 \mathrm{~km}^{2}$. The high and very high sites were located near the urban nucleus and close to the national road (RN11), and they cover a sector of $13.249 \mathrm{~km}^{2}$ and $6.834 \mathrm{~km}^{2}$, respectively. A very high landslide density is observed near these anthropogenic features (Figure 6). The high and very high classes were located mainly in the Western part; they were estimated as $72.24 \%\left(9.604 \mathrm{~km}^{2}\right)$ and $79.19 \%\left(5.142 \mathrm{~km}^{2}\right)$. 
The Eastern part records a high susceptible area of $3.689 \mathrm{~km}^{2}(27.75 \%)$. The very high class covers an area of $1.422 \mathrm{~km}^{2}(20.80 \%)$, and these dangerous sites are mostly situated in the fallow land class.
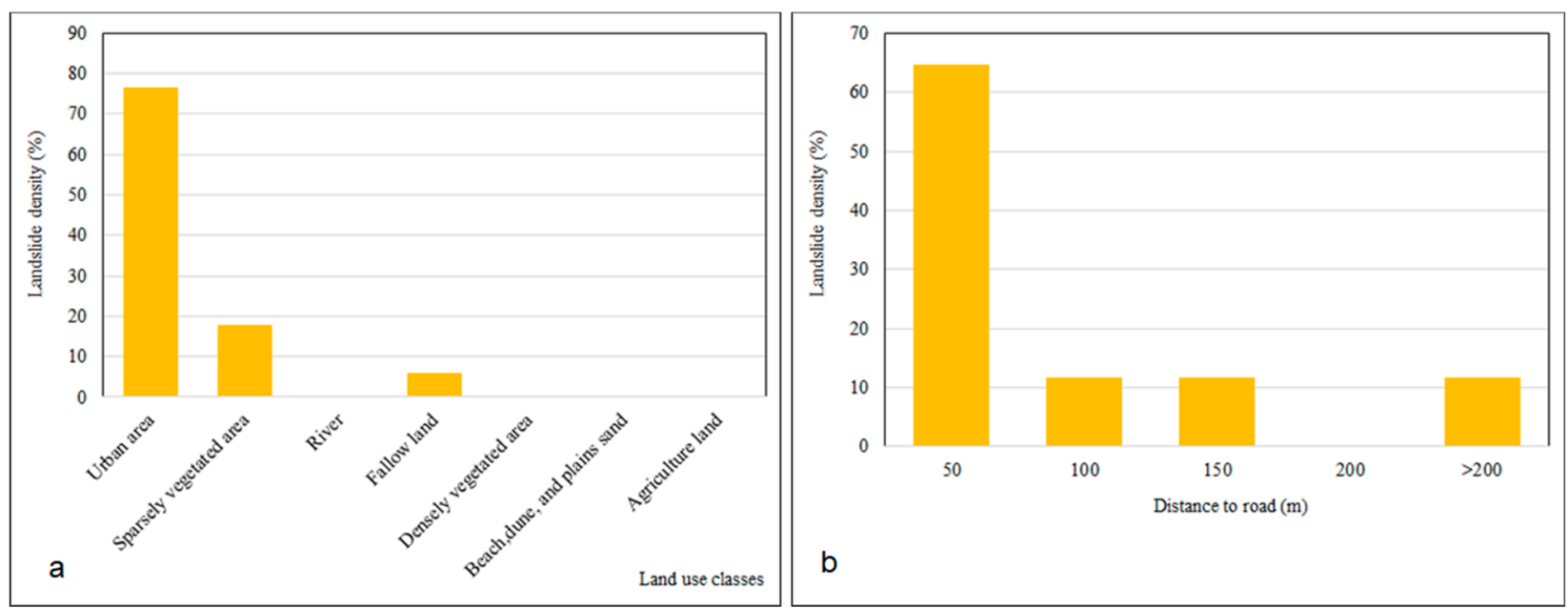

Figure 6. Landslide density: (a) Land Use (LU) map and (b) distance to road.

LSM, utilizing the knowledge-driven approach, was comparable to that drawn by means of the AHP method (Figure $5 b$ ). With respect to this, the very low class corresponds to the forests, which occupy an area of $4.05 \mathrm{~km}^{2}$ (7.82\%). However, regions with low landslide susceptibility are located in the coastal sand features, of which the class covers $10.63 \mathrm{~km}^{2}(20.53 \%)$. The moderate zones, mainly located in the Western part of the province, cover an area of $15.84 \mathrm{~km}^{2}(30.6 \%)$. Finally, the high and very high susceptibility classes, predominant in the Western urban zone, cover extended areas of $16.197 \mathrm{~km}^{2}(31.29 \%)$ and $5.047 \mathrm{~km}^{2}(9.75 \%)$, respectively.

Zones with a very low susceptibility to landslides were registered in areas with dense vegetation. Vegetation plays an important role in enhancing slope stability and reducing landslide susceptibility [97]. Zones with the lowest landslide susceptibility are located along beaches, mobile dunes, and sand plains (Figure 5). Generally, these zones are flat and do not register any event in this land cover class. The regions with moderate landslide susceptibility were identified close to built-up areas and in fallow land. Due to the predominance of streams, the zones with high and very high susceptibility were recorded in the urban nucleus and close to the national road (RN11). In the coastal district of Mostaganem, most human settlements were constructed in the quaternary continental alluvium and sand classes. Both lithological types have weak shear strength when hydrogeological conditions are favourable, leading to an increase in landslide susceptibility. In this respect, the quaternary continental alluvium recorded high landslide event density, which has been estimated at about $52.94 \%$ (Figure 7 ). The results obtained show clearly that the density of landslide events increases with the susceptibility degree (Table 5). The current situation in Mostaganem is due to unplanned and uncontrolled use of this area. Since 2000, the landscape of the Mostaganem coast district has undergone an important alteration due to the excessive exploitation of natural resources and uncontrolled expansion of residential buildings, regardless of environmental impacts (slope cutting, floods) and in spite of the Littoral Law, which should protect the coastal zone [98]. The situation in the Mostaganem coast district reflects a major lack of planning during the urbanization process $[45,99]$. 


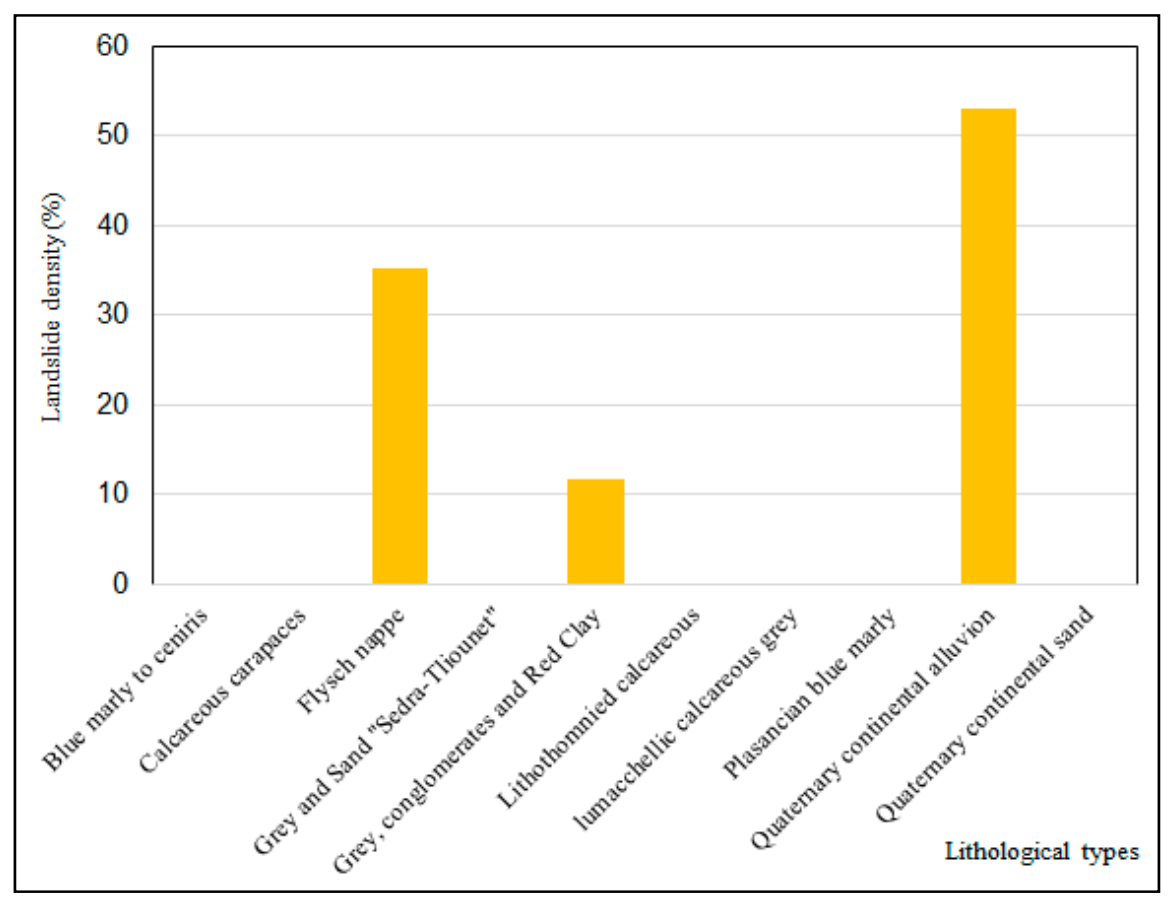

Figure 7. Landslide density extracted from the lithology map.

Table 5. Landslide susceptibility classes area.

\begin{tabular}{ccccc}
\hline \multirow{2}{*}{ Susceptibility Classes } & \multicolumn{2}{c}{ Knowledge Driven Approach } & \multicolumn{2}{c}{ AHP Method } \\
\cline { 2 - 5 } & Area $\mathbf{( k m}^{\mathbf{2}} \mathbf{~}$ & L.D (\%) & Area $\mathbf{( k m}^{\mathbf{2}} \mathbf{)}$ & L. D (\%) \\
\hline Very low & 3.823 & 0 & 4.05 & 0 \\
Low & 11.484 & 5.882 & 10.63 & 11.765 \\
Moderate & 16.329 & 11.765 & 15.84 & 11.765 \\
High & 13.294 & 35.294 & 16.197 & 23.529 \\
Very high & 6.834 & 47.059 & 5.047 & 52.941 \\
\hline
\end{tabular}

L.D: landslide density per class.

\subsection{Validation of Landslide Susceptibility Maps}

Evaluation of the quality of predictive landslide maps represents a primary step in this field. Therefore, different methods were attempted, such as landslide density analysis $\left(\mathrm{L}_{\mathrm{d}}\right)$, Prediction Rate Curve (PRC), and Area Under Curve (AUC) of Receiver Operating Characteristic curve (ROC) [100]. In this work, two methods were applied. The first method is based on the utilization of the ground truth map of landslides with the aim to compare the produced landslide susceptibility maps. The quality of these maps was concluded in comparison to the ground truth map (Figure 5). In order to achieve the objective of this method, a numerical scale (1-5) has been assigned to the predictive map classes. The lowest value corresponds to zones with lower susceptibility to landslides; the highest value corresponds to areas with higher susceptibility to landslides (Table 6). Furthermore, two assumptions based on the location of the landslide event on the ground truth map of the landslide were taken:

1. The landslide event is located in the same susceptibility class (Figure 5), the result is outstanding, and the choice of the model was correct.

2. The landslide event is located in two different susceptibility classes (degree), and two hypotheses could be considered:

- If the difference between the classes of the two predictive maps is one (1), the choice of the model is accepted.

- If the difference is higher than one $(>1)$, the model should be revised. 
Table 6. Assignment of numerical scale to landslide susceptibility classes.

\begin{tabular}{cc}
\hline Landslide Susceptibility Classes & Numerical Scale \\
\hline Very low & 1 \\
Low & 2 \\
Moderate & 3 \\
High & 4 \\
Very high & 5 \\
\hline
\end{tabular}

Based on the comparison (Table 7), 59\% of the landslide events are located in the same landslide susceptibility degree, which means that the choice of the models was correct. In contrast, $41 \%$ of cases indicate that they belong to two distinct classes with a difference equal to one (1). This analysis reflects the acceptable choice of the models.

Table 7. Comparison of the event location for the two methods.

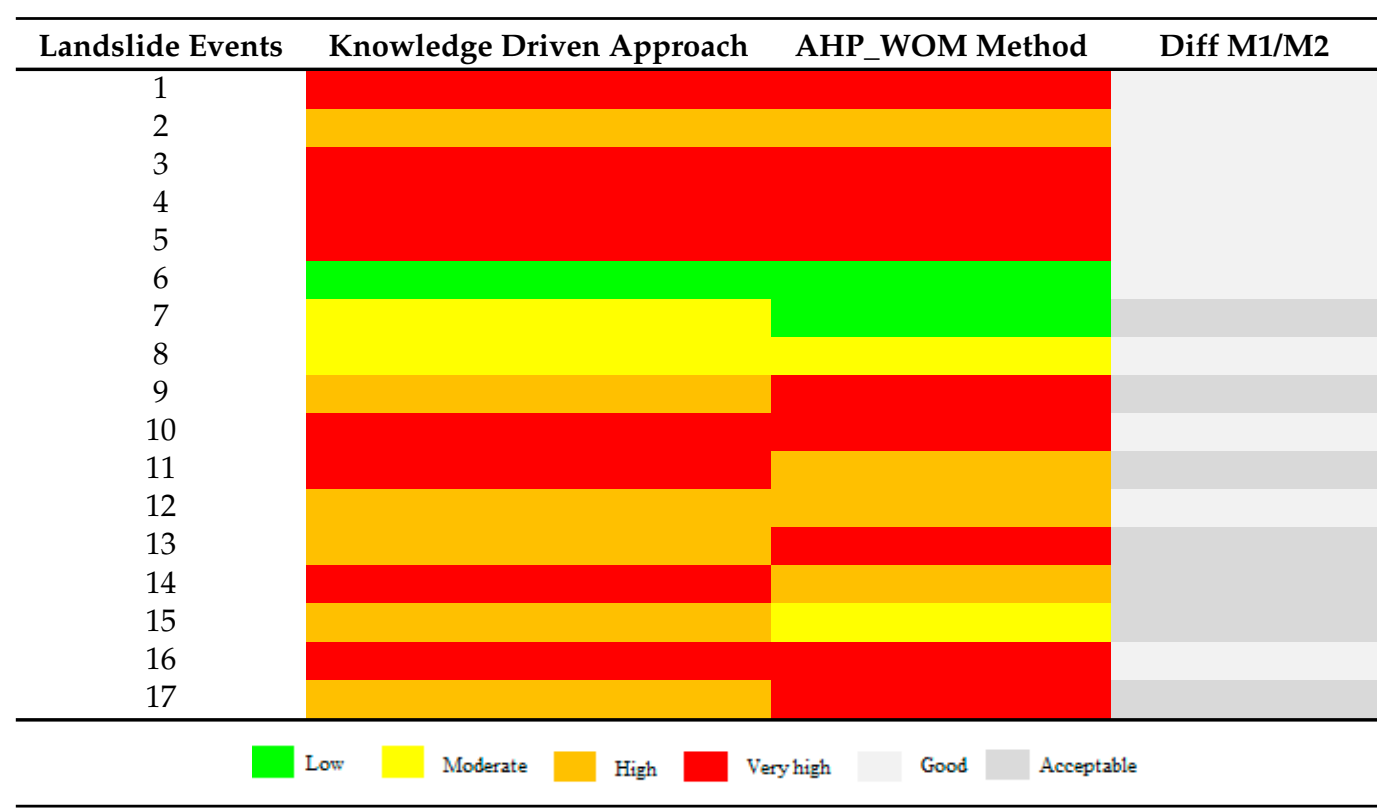

The second method was the Receiver Operating Characteristic curve (ROC), which is a static technique used by researchers to validate predictive results [101]. In this case, a graphical plot that provides analysis based on true-positive and false-positive rates (sensitivity $=\mathrm{f}$ (specificity)) represented the ROC. When this method is applied, the generated Area Under Curve (AUC), of which the value could change in different cases, shows the reliability of the model used. Accordingly, values ranging from 0.5 to 1 indicate that the model is correct; values $<0.5$ indicate a random fit. In this work, we calculated the AUC using XLSTAT software (version 2015). The results of the predictive maps show that the layer, based on the knowledge-driven approach, has an accuracy of AUC $=0.686$. For the map based on the Analytical Hierarchy Process (AHP) combined with WO, the ROC showed a better accuracy $(\mathrm{AUC}=0.753)$ (Figure 8$)$. These values indicate that the used models are suitable for landslide susceptibility mapping. Based on the techniques used, the landslide predictive maps of landslides show acceptable results. 


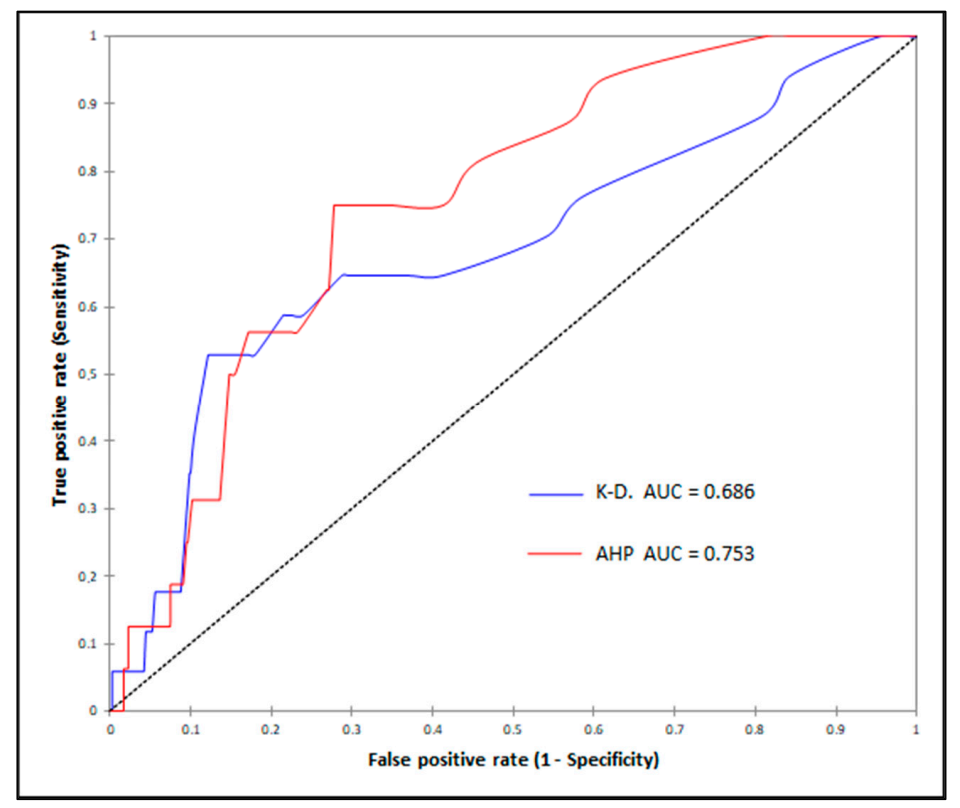

Figure 8. Receiver Operating Characteristic (ROC) curve assessment of two methods applied.

\section{Conclusions}

Landslide hazards impose enormous constraints on socioeconomic development. Many methods have been attempted for landslide zonation, including qualitative and quantitative approaches. In this research, we used a semi-quantitative method, applying the analytical hierarchy process (AHP) and knowledge-driven approaches; the two produced layers presented common points. In effect, we identified zones with low and very low landslide susceptibility in densely vegetated sites, as well as beach and coastal dune areas. However, zones with high and very high susceptibility were registered in the urban nucleus and close to the national road, RN11; strong water streams characterized both places. Regarding the distance to fault, the values confirmed that this parameter has a weak influence on landslide occurrence. The predictive landslide susceptibility maps were evaluated using the ground truth map of landslide and the Receiver Operating Characteristic curve (ROC). The ground truth map of landslides confirmed that the modelled maps present outstanding reliability, considering the location of the landslide events. Meanwhile, validation based on the ROC indicates an accuracy of 0.686 ( $\mathrm{AUC}=0.686$ ) regarding the map produced using the knowledge-driven approach. The realized map using the AHP combined with the weighted overlay method showed a higher accuracy (AUC $=0.753$ ). Both techniques proved that the achieved results are scientifically correct compared with other works. The landscape of the Mostaganem province is mainly formed by a brittle lithology. Many construction projects have been launched in the vulnerable sandy coastal features, regardless of the Algerian littoral law that prohibits it. Poorly planned construction projects in low resilience areas, realized without adequate grading of slopes and control of the hydrographic network, contribute to landslides triggering. The realized maps could be used to monitor the spread of landslides and prevent possible natural disaster. The local authorities of Mostaganem have set an economic development program until 2030. In this regard, the landslide susceptibility map could help decision makers to better design future construction projects and avoid building in highly susceptible zones.

Author Contributions: R.S. contributed to the article by conceptualization, literature review, investigation, data collection, modeling, validation, visualization, and writing the original draft; N.E.-T. planned and supervised the field work activities, interpreted the data and reviewed the final draft of the manuscript; A.C.T. and L.D. supervised the methodological activities, provided the valuable comments in writing this paper and reviewed the final draft of manuscript; H.M. provided a valu- 
able comment in landslide phenomenon; R.Y.M. contributed conception to the geo database and the reviewed the final draft. All authors have read and agreed to the published version of the manuscript.

Funding: This work was funded as a part of Erasmus project between the University of Mostaganem (Algeria) and the University of Porto (Portugal), and by the National Funds through FCTFoundation for Science and Technology under the project UIDB/04683/2020.

Institutional Review Board Statement: Not applicable.

Informed Consent Statement: Not applicable.

Data Availability Statement: Not applicable.

Acknowledgments: We thank the General Directorate for Scientific Research and Technological Development, we thank too as well the National Coastal Commission (Commissariat National $\mathrm{du}$ Littoral) of Mostaganem, the Directorate of Public Works of Mostaganem and the map library (cartothèque) of the University of Oran. We would like thank too William Edmonson for revising the paper and providing the valuable comments.

Conflicts of Interest: The authors declare no conflict of interest.

\section{References}

1. Amod, D.S.; Takaaki, A.; Masamu, A. Landslide hazard mapping and its evaluation using GIS: An investigation of sampling schemes for a grid-cell based quantitative method. Photogramm. Eng. Remote Sens. 2000, 66, 981-989.

2. Galli, M.; Ardizzone, F.; Cardinali, M.; Guzzetti, F.; Reichenbach, P. Comparing landslide inventory maps. Geomorphology 2008, 94, 268-289. [CrossRef]

3. Shanmugam, G.; Wang, Y. The landslide problem. J. Palaeogeogr. 2015, 4, 109-166. [CrossRef]

4. Rahamana, S.A.; Aruchamy, S.; Jegankumar, R. Geospatial Approach on Landslide Hazard Zonation Mapping Using Multicriteria Decision Analysis: A Study on Coonoor and Ooty, Part of Kallar Watershed, The Nilgiris, Tamil Nadu. ISPRS Int. Arch. Photogramm. Remote Sens. Spat. Inf. Sci. 2014, 1417-1422. [CrossRef]

5. Pham, B.T.; Shirzadi, A.; Shahabi, H.; Omidvar, E.; Singh, S.K.; Sahana, M.; Asl, D.T.; Ahmad, B.B.; Quoc, N.K.; Lee, S. Landslide Susceptibility Assessment by Novel Hybrid Machine Learning Algorithms. Sustainability 2019, 11, 4386. [CrossRef]

6. Calcaterra, D.; Parise, M. Landslide types and their relationships with weathering in a Calabrian basin, southern Italy. Bull. Int. Assoc. Eng. Geol. 2005, 64, 193-207. [CrossRef]

7. Froude, M.J.; Petley, D.N. Global fatal landslide occurrence from 2004 to 2016. Nat. Hazards Earth Syst. Sci. 2018, 18, $2161-2181$. [CrossRef]

8. Ali, S.; Biermanns, P.; Haider, R.; Reicherter, K. Landslide susceptibility mapping by using a geographic information system (GIS) along the China-Pakistan Economic Corridor (Karakoram Highway), Pakistan. Nat. Hazards Earth Syst. Sci. 2019, 19, 999-1022. [CrossRef]

9. Hidalgo, C.; Vega, J.A.; Obando, M.P. Effect of the Rainfall Infiltration Processes on the Landslide Hazard Assessment of Unsaturated Soils in Tropical Mountainous Regions. In Engineering and Mathematical Topics in Rainfall; IntechOpen: London, UK, 2018.

10. Prakash, N.; Manconi, A.; Loew, S. Mapping Landslides on EO Data: Performance of Deep Learning Models vs. Traditional Machine Learning Models. Remote Sens. 2020, 12, 346. [CrossRef]

11. Wang, Q.; Wang, D.; Huang, Y.; Wang, Z.; Zhang, L.; Guo, Q.; Chen, W.; Chen, W.; Sang, M. Landslide Susceptibility Mapping Based on Selected Optimal Combination of Landslide Predisposing Factors in a Large Catchment. Sustainability 2015, 7, 1665316669. [CrossRef]

12. Machane, D.; Bouhadad, Y.; Cheikhlounis, G.; Chatelain, J.L.; Oubaiche, E.H.; Abbès, K.; Guillier, B.; Bensalem, R. Examples of geomorphologic and geological hazards in Algeria. Nat. Hazards 2008, 45, 295-308. [CrossRef]

13. Djerbal, L. Analyse des Mécanismes de déFormation et de la Rupture Progressive du Versant Instable d'Ain El Hammam. Ph.D. Thesis, Université Mouloud Mammeri de Tizi-Ouzou, Tizi-Ouzou, Algeria, 2013.

14. Guzzetti, F.; Carrara, A.; Cardinali, M.; Reichenbach, P. Landslide hazard evaluation: A review of current techniques and their application in a multi-scale study, Central Italy. Geomorphology 1999, 31, 181-216. [CrossRef]

15. Hadmoko, D.S.; Lavigne, F.; Sartohadi, J.; Hadi, P.; Winaryo, P. Landslide hazard and risk assessment and their application in risk management and landuse planning in eastern flank of Menoreh Mountains, Yogyakarta Province, Indonesia. Nat. Hazards 2010, 54, 623-642. [CrossRef]

16. Hadji, R.; Achour, Y.; Hamed, Y. Using GIS and RS for Slope Movement Susceptibility Mapping: Comparing AHP, LI and LR Methods for the Oued Mellah Basin, NE Algeria. In Collaboration and Integration in Construction, Engineering, Management and Technology; Springer: Berlin/Heidelberg, Germany, 2018; pp. 1853-1856.

17. Pourghasemi, H.R.; Pradhan, B.; Gokceoglu, C. Application of fuzzy logic and analytical hierarchy process (AHP) to landslide susceptibility mapping at Haraz watershed, Iran. Nat. Hazards 2012, 63, 965-996. [CrossRef]

18. Soeters, R.; Van Westen, C.J. Slope instability recognition, analysis and zonation. Landslides Investig. Mitig. 1996, $247,129-177$. 
19. Aleotti, P.; Baldelli, P.; Polloni, G. Landsliding and Flooding Event Triggered by Heavy Rains in the Tanaro Basin (Italy). 1996. Available online: http://www.interpraevent.at/palm-cms/upload_files/Publikationen/Tagungsbeitraege/1996_1_435.pdf (accessed on 11 January 2021).

20. Ayalew, L.; Yamagishi, H. The application of GIS-based logistic regression for landslide susceptibility mapping in the KakudaYahiko Mountains, Central Japan. Geomorphology 2005, 65, 15-31. [CrossRef]

21. Pardeshi, S.D.; Autade, S.E.; Pardeshi, S.S. Landslide hazard assessment: Recent trends and techniques. SpringerPlus 2013, 2. [CrossRef]

22. Mahalingam, R.; Olsen, M.J.; O’Banion, M.S. Evaluation of landslide susceptibility mapping techniques using lidar-derived conditioning factors (Oregon case study). Geomat. Nat. Hazards Risk 2016, 7, 1884-1907. [CrossRef]

23. Lee, S. Landslide susceptibility mapping using an artificial neural network in the Gangneung area, Korea. Int. J. Remote Sens. 2007, 28, 4763-4783. [CrossRef]

24. Thiery, Y.; Terrier, M. Évaluation de l'aléa glissements de terrain: État de l'art et perspectives pour la cartographie réglementaire en France. Revue Française Géotechnique 2019, 156. [CrossRef]

25. Saadatkhah, N.; Kassim, A.; Lee, L.M. Qualitative and quantitative landslide susceptibility assessments in Hulu Kelang area Malaysia. Electron. J. Geotech. Eng. 2014, 19, 545-563.

26. Mandaglio, M.C.; Gioffrè, D.; Pitasi, A.; Moraci, N. Qualitative Landslide Susceptibility Assessment in Small Areas. Procedia Eng. 2016, 158, 440-445. [CrossRef]

27. Van Westen, C.J.; Rengers, N.; Soeters, R. Use of Geomorphological Information in Indirect Landslide Susceptibility Assessment. Nat. Hazards 2003, 30, 399-419. [CrossRef]

28. Gupta, S.K.; Shukla, D.P.; Thakur, M. Selection of weightages for causative factors used in preparation of landslide susceptibility zonation (LSZ). Geomat. Nat. Hazards Risk 2018, 9, 471-487. [CrossRef]

29. Saaty, T.L. The Analytic Hierarchy Process; McGraw-Hill: New York, NY, USA, 1980.

30. Vakhshoori, V.; Pourghasemi, H.R.; Zare, M.; Blaschke, T. Landslide Susceptibility Mapping Using GIS-Based Data Mining Algorithms. Water 2019, 11, 2292. [CrossRef]

31. Zhou, G.; Esaki, T.; Mitani, Y.; Xie, M.; Mori, J. Spatial probabilistic modeling of slope failure using an integrated GIS Monte Carlo simulation approach. Eng. Geol. 2003, 68, 373-386. [CrossRef]

32. Van Westen, C.J.; Rengers, N.; Terlien, M.T.J.; Soeters, R. Prediction of the occurrence of slope instability phenomenal through GIS-based hazard zonation. Acta Diabetol. 1997, 86, 404-414. [CrossRef]

33. Lee, S.; Min, K. Statistical analysis of landslide susceptibility at Yongin, Korea. Environ. Earth Sci. 2001, 40, 1095-1113. [CrossRef]

34. Yesilnacar, E.; Topal, T. Landslide susceptibility mapping: A comparison of logistic regression and neural networks methods in a medium scale study, Hendek region (Turkey). Eng. Geol. 2005, 79, 251-266. [CrossRef]

35. Nefeslioglu, H.A.; Gokceoglu, C.; Sonmez, H. An assessment on the use of logistic regression and artificial neural networks with different sampling strategies for the preparation of landslide susceptibility maps. Eng. Geol. 2008, 97, 171-191. [CrossRef]

36. Choi, J.; Oh, H.J.; Lee, H.J.; Lee, C.; Lee, S. Combining landslide susceptibility maps obtained from frequency ratio, logistic regression, and artificial neural network models using ASTER images and GIS. Eng. Geol. 2012, 124, 12-23. [CrossRef]

37. Pradhan, B.; Lee, S. Landslide susceptibility assessment and factor effect analysis: Backpropagation artificial neural networks and their comparison with frequency ratio and bivariate logistic regression modelling. Environ. Model. Softw. 2010, 25, 747-759. [CrossRef]

38. Yalcin, A.; Reis, S.; Aydinoglu, A.; Yomralioglu, T. A GIS-based comparative study of frequency ratio, analytical hierarchy process, bivariate statistics and logistics regression methods for landslide susceptibility mapping in Trabzon, NE Turkey. Catena 2011, 85, 274-287. [CrossRef]

39. Vakhshoori, V.; Zare, M. Landslide susceptibility mapping by comparing weight of evidence, fuzzy logic, and frequency ratio methods. Geomat. Nat. Hazards Risk 2016, 7, 1731-1752. [CrossRef]

40. Bourenane, H.; Bouhadad, Y.; Guettouche, M.S.; Braham, M. GIS-based landslide susceptibility zonation using bivariate statistical and expert approaches in the city of Constantine (Northeast Algeria). Bull. Int. Assoc. Eng. Geol. 2014, 74, 337-355. [CrossRef]

41. Dahoua, L.; Yakovitch, S.; Hadji, R.H. GIS-based technic for roadside-slope stability assessment: A bivariate approach for A1 East-west highway, North Algeria. Min. Sci. 2017, 24. [CrossRef]

42. Achour, Y.; Boumezbeur, A.; Hadji, R.; Chouabbi, A.; Cavaleiro, V.; Bendaoud, E.A. Landslide susceptibility mapping using analytic hierarchy process and information value methods along a highway road section in Constantine, Algeria. Arab. J. Geosci. 2017, 10, 194. [CrossRef]

43. Manchar, N.; Benabbas, C.; Hadji, R.; Bouaicha, F.; Grecu, F. Landslide Susceptibility Assessment in Constantine Region (NE Algeria) By Means of Statistical Models. Stud. Geotech. Mech. 2018, 40, 208-219. [CrossRef]

44. Roukh, Z.E.A.; Abdelmansour, N. Landslide susceptibility mapping using information value and frequency ratio for the Arzew sector (North-Western of Algeria). Bull. Miner. Res. Explor. 2018, 1-10. [CrossRef]

45. Senouci, R.; Taibi, N.E. Impact of the Urbanization on Coastal Dune: Case of Kharrouba, West of Algeria. J. Sediment. Environ. 2019, 4, 90-98. [CrossRef]

46. Bourenane, H.; Guettouche, M.S.; Bouhadad, Y.; Braham, M. Landslide hazard mapping in the Constantine city, Northeast Algeria using frequency ratio, weighting factor, logistic regression, weights of evidence, and analytical hierarchy process methods. Arab. J. Geosci. 2016, 9, 1-24. [CrossRef] 
47. Agence Nationale d'Aménagement de Territoire. Plan d'Aménagement Côtier; Rapport; ANAT: Kouba, Algérie, 2005.

48. Taibi, N.E. Conflict between Coastal Tourism Development and Sustainability: Case of Mostaganem, Western Algeria. Eur. J. Sustain. Dev. 2016, 5, 13-24. [CrossRef]

49. Godbani, T. Environnement et Littoralisation de l'Ouest Algérien. Ph.D. Thesis, Université d'Oran 2, Oran, Algeria, 2009.

50. Caïd, N.; Chachoua, M.; Berrichi, F. Analyse spatiale diachronique de l'occupation du vignoble algérien depuis 60 ans: Cas de la wilaya de Mostaganem. Physio-Géo Géographie Physique Environ. 2019, 13, 53-74. [CrossRef]

51. Megherbi, W. L'ensablement, Un Risque Négligé en Zone Tellienne Littorale Cas de la Région Mostaganem. Master's Thesis, Université d'Oran 2, Oran, Algeria, 2015.

52. Zaoui, M. Système D'information Géographique et Méthodologie Multicritère pour le Choix de Sites de Retenues Collinaires: Application pour la Wilaya de Mostaganem, Algérie. Ph.D. Thesis, Université de Mostaganem, Mostaganem, Algeria, 2015.

53. Senouci, M.; Trache, A.E.H. Etude de la Vulnérabilité aux Changement Climatiques de la Wilaya de Mostaganem; Deutsche Gesellschaft für Internationale Zusammenarbeit (GIZ) GmbH: Ageria, Algeria, 2014.

54. Del Ventisette, C.; Righini, G.; Moretti, S.; Casagli, N. Multitemporal landslides inventory map updating using spaceborne SAR analysis. Int. J. Appl. Earth Obs. Geoinf. 2014, 30, 238-246. [CrossRef]

55. Moosavi, V.; Talebi, A.; Shirmohammadi, B. Producing a landslide inventory map using pixel-based and object-oriented approaches optimized by Taguchi method. Geomorphology 2014, 204, 646-656. [CrossRef]

56. Guzzetti, F.; Reichenbach, P.; Cardinali, M.; Galli, M.; Ardizzone, F. Probabilistic landslide hazard assessment at the basin scale. Geomorphology 2005, 72, 272-299. [CrossRef]

57. Van Westen, C.J.; Van Asch, T.W.J.; Soeters, R. Landslide hazard and risk zonation-Why is it still so difficult? Bull. Eng. Geol. Environ. 2006, 65, 167-184. [CrossRef]

58. Guri, P.K.; Ray, P.K.C.; Patel, R.C. Spatial prediction of landslide susceptibility in parts of Garhwal Himalaya, India, using the weight of evidence modelling. Environ. Monit. Assess. 2015, 187, 1-25. [CrossRef]

59. Cardinali, M.; Reichenbach, P.; Guzzetti, F.; Ardizzone, F.; Antonini, G.; Galli, M.; Cacciano, M.; Castellani, M.; Salvati, P. A geomorphological approach to the estimation of landslide hazards and risks in Umbria, Central Italy. Nat. Hazards Earth Syst. Sci. 2002, 2, 57-72. [CrossRef]

60. Igwe, O. The geotechnical characteristics of landslides on the sedimentary and metamorphic terrains of South-East Nigeria, West Africa. Geoenviron. Disasters 2015, 2, 1. [CrossRef]

61. Kouli, M.; Loupasakis, C.; Soupios, P.; Vallianatos, F. Landslide hazard zonation in high risk areas of Rethymno Prefecture, Crete Island, Greece. Nat. Hazards 2009, 52, 599-621. [CrossRef]

62. Awawdeh, M.; Elmughrabi, M.A.; Atallah, M.Y. Landslide susceptibility mapping using GIS and weighted overlay method: A case study from North Jordan. Environ. Earth Sci. 2018, 77, 732. [CrossRef]

63. Pham, B.T.; Bui, D.T.; Dholakia, M.; Prakash, I.; Pham, H.V.; Mehmood, K.; Le, H.Q. A novel ensemble classifier of rotation forest and Naïve Bayer for landslide susceptibility assessment at the Luc Yen district, Yen Bai Province (Viet Nam) using GIS. Geomat. Nat. Hazards Risk 2016, 8, 649-671. [CrossRef]

64. Gokceoglu, M.E.C. Assessment of landslide susceptibility for a landslide-prone area (north of Yenice, NW Turkey) by fuzzy approach. Environ. Geol. 2002, 41, 720-730. [CrossRef]

65. Glade, T. Landslide occurrence as a response to land use change: A review of evidence from New Zealand. Catena 2003, 51, 297-314. [CrossRef]

66. Hong, H.; Pradhan, B.; Bui, D.T.; Xu, C.; Youssef, A.M.; Pourghasemi, H.R. Comparison of four kernel functions used in support vector machines for landslide susceptibility mapping: A case study at Suichuan area (China). Geomat. Nat. Hazards Risk 2017, 8, 544-569. [CrossRef]

67. Perera, E.N.C.; Jayawardana, D.T.; Jayasinghe, P.; Bandara, R.M.S.; Alahakoon, N. Direct impacts of landslides on socio-economic systems: A case study from Aranayake, Sri Lanka. Geoenviron. Disasters 2018, 5, 11. [CrossRef]

68. Saha, A.K.; Gupta, R.P.; Arora, M.K. GIS-based Landslide Hazard Zonation in the Bhagirathi (Ganga) Valley, Himalayas. Int. J. Remote Sens. 2002, 23, 357-369. [CrossRef]

69. Teodoro, A.C.; Pais-Barbosa, J.; Gonçalves, H.; Veloso-Gomes, F.; Taveira-Pinto, F. Identification of beach hydromorphological patterns/forms through image classification techniques applied to remotely sensed data. Int. J. Remote Sens. 2011, 32, 7399-7422. [CrossRef]

70. Kayastha, P.; Dhital, M.; De Smedt, F. Application of the analytical hierarchy process (AHP) for landslide susceptibility mapping: A case study from the Tinau watershed, west Nepal. Comput. Geosci. 2013, 52, 398-408. [CrossRef]

71. Roşian, G.; Csaba, H.; Kinga-Olga, R.; Boţan, C.N.; Gavrilă, I.G. Assessing landslide vulnerability using bivariate statistical analysis and the frequency ratio model. Case study: Transylvanian Plain (Romania). Z. Geomorphol. 2016, 60, 359-371. [CrossRef]

72. Sifa, S.F.; Mahmud, T.; Tarin, M.A.; Haque, D.M.E. Event-based landslide susceptibility mapping using weights of evidence (WoE) and modified frequency ratio (MFR) model: A case study of Rangamati district in Bangladesh. Geol. Ecol. Landsc. 2019, 1-14. [CrossRef]

73. Wilson, J.P.; Gallant, J.C. Terrain Analysis: Principles and Applications; John Wiley \& Sons: Hoboken, NJ, USA, 2000.

74. Zhu, A.X.; Wang, R.; Qiao, J.; Qin, C.Z.; Chen, Y.; Liu, J.; Du, F.; Lin, Y.; Zhu, T. An expert knowledge-based approach to landslide susceptibility mapping using GIS and fuzzy logic. Geomorphology 2014, 214, 128-138. [CrossRef] 
75. Bălteanu, D.; Chendeş, V.; Sima, M.; Enciu, P. A country-wide spatial assessment of landslide susceptibility in Romania. Geomorphology 2010, 124, 102-112. [CrossRef]

76. Anis, Z.; Wissem, G.; Vali, V.; Smida, H.; Essghaier, G.M. GIS-based landslide susceptibility mapping using bivariate statistical methods in North-western Tunisia. Open Geosci. 2019, 11, 708-726. [CrossRef]

77. Mousavi, S.Z.; Kavian, A.; Soleimani, K.; Mousavi, S.R.; Shirzadi, A. GIS-based spatial prediction of landslide susceptibility using logistic regression model. Geomatics Nat. Hazards Risk 2011, 2, 33-50. [CrossRef]

78. Wang, F.; Xu, P.; Wang, C.M.; Wang, N.; Jiang, N. Application of a GIS-Based Slope Unit Method for Landslide Susceptibility Mapping along the Longzi River, Southeastern Tibetan Plateau, China. ISPRS Int. J. GeoInformation 2017, 6, 172. [CrossRef]

79. Baiche, A.; Mohamed, H.S.; Ablaoui, H. Surexploitation des ressources en eau de l'aquifere du plateau de Mostaganem. LARHYSS J.l 2015, 22, 153-165.

80. Saibi, H. Etude Hydrogéologique du Plateau de Mostaganem (Nord-ouest Algérien): Géologie, Géophysique, Climatologie, Hydrodynamisme, Hydrochimie et Vulnérabilité des Eaux Souterraines à la Pollution par la Méthode DRASTIC; Éditions Universitaires Européennes: Saarbrücken, Germany, 2010.

81. Chen, C.Y.; Huang, W.L. Land use change and landslide characteristics analysis for community-based disaster mitigation. Environ. Monit. Assess. 2012, 185, 4125-4139. [CrossRef]

82. Arca, D.; Kutoglu, S.H.; Becek, K. Landslide susceptibility mapping in an area of underground mining using the multicriteria decision analysis method. Environ. Monit. Assess. 2018, 190, 1-14. [CrossRef]

83. Ghosh, S.; Das, R.; Goswami, B. Developing GIS-based techniques for application of knowledge and data-driven methods of landslide susceptibility mapping. Indian J. Geosci. 2013, 67, 249-272.

84. Kaur, H.; Gupta, S.; Parkash, S.; Thapa, R. Knowledge-driven method: A tool for landslide susceptibility zonation (LSZ). Geol. Ecol. Landscapes 2018, 1-15. [CrossRef]

85. Rabehi, W.; Guerfi, M.; Mahi, H. Cartographie de la Vulnérabilité des Communes de la Baie d'Alger. Approche Socio-économique et Physique de la côte. Mediterranee. 2018. Available online: https://journals.openedition.org/mediterranee/8625 (accessed on 11 January 2021).

86. Michael, E.A.; Samanta, S. Landslide vulnerability mapping (LVM) using weighted linear combination (WLC) model through remote sensing and GIS techniques. Model. Earth Syst. Environ. 2016, 2, 1-15. [CrossRef]

87. Shit, P.K.; Bhunia, G.S.; Maiti, R. Potential landslide susceptibility mapping using weighted overlay model (WOM). Model. Earth Syst. Environ. 2016, 2, 1-10. [CrossRef]

88. Ahmed, M.F.; Rogers, J.D.; Ismail, E.H. A regional level preliminary landslide susceptibility study of the upper Indus river basin. Eur. J. Remote Sens. 2014, 47, 343-373. [CrossRef]

89. Basharat, M.; Shah, H.R.; Hameed, N. Landslide susceptibility mapping using GIS and weighted overlay method: A case study from NW Himalayas, Pakistan. Arab. J. Geosci. 2016, 9, 1-19. [CrossRef]

90. Zadeh, L.A. Information and control. Fuzzy Sets 1965, 8, 338-353.

91. Zimmermann, H.J. Fuzzy set theory. Wiley Interdiscip. Rev. Comput. Stat. 2010, 2, 317-332. [CrossRef]

92. Carranza, E.J.M.; Hale, M. Geologically Constrained Fuzzy Mapping of Gold Mineralization Potential, Baguio District, Philippines. Nat. Resour. Res. 2001, 10, 125-136. [CrossRef]

93. Ilanloo, M. A comparative study of fuzzy logic approach for landslide susceptibility mapping using GIS: An experience of Karaj dam basin in Iran. Procedia Soc. Behav. Sci. 2011, 19, 668-676. [CrossRef]

94. Feizizadeh, B.; Roodposhti, M.S.; Jankowski, P.; Blaschke, T. A GIS-based extended fuzzy multi-criteria evaluation for landslide susceptibility mapping. Comput. Geosci. 2014, 73, 208-221. [CrossRef] [PubMed]

95. Mijani, N.; Samani, N.N. Comparison of Fuzzy-based Models in Landslide Hazard Mapping. ISPRS Int. Arch. Photogramm. Remote Sens. Spat. Inf. Sci. 2017, 407-416. [CrossRef]

96. Mokarram, M.; Zarei, A.R. Landslide Susceptibility Mapping Using Fuzzy-AHP. Geotech. Geol. Eng. 2018, 36, 3931-3943. [CrossRef]

97. Miles, S.B.; Keefer, D.K. Comprehensive Areal Model of Earthquake-Induced Landslides: Technical Specification and User Guide; Open File Report; USGS: Reston, VA, USA, 2007.

98. Akgun, A.; Kıncal, C.; Pradhan, B. Application of remote sensing data and GIS for landslide risk assessment as an environmental threat to Izmir city (west Turkey). Environ. Monit. Assess. 2012, 184, 5453-5470. [CrossRef]

99. Karsli, F.; Atasoy, M.; Yalcin, A.; Reis, S.; Demir, O.; Gokceoglu, C. Effects of land-use changes on landslides in a landslide-prone area (Ardesen, Rize, NE Turkey). Environ. Monit. Assess. 2008, 156, 241-255. [CrossRef]

100. Vakhshoori, V.; Zare, M. Is the ROC curve a reliable tool to compare the validity of landslide susceptibility maps? Geomat. Nat. Hazards Risk 2018, 9, 249-266. [CrossRef]

101. Lin, L.; Lin, Q.; Wang, Y. Landslide susceptibility mapping on a global scale using the method of logistic regression. Nat. Hazards Earth Syst. Sci. 2017, 17, 1411-1424. [CrossRef] 